\title{
Organisation development: The argument still stands
}

\section{Clive Smith}

Department of Education Leadership and Management, University of Johannesburg, Johannesburg, South Africa

csmith@uj.ac.za

https://orcid.org/0000-0002-3375-7785

\section{Marion Mackinnon}

Department of Education Leadership and Management, University of Johannesburg, Johannesburg, South Africa

mack@mweb.co.za

https://orcid.org/0000-0003-2147-147X

(Received: 24 August 2019; accepted: 30 October 2019)

\section{Abstract}

After the national transition in 1994, South Africa was welcomed back into the international political and economic arena. Becoming part of the global community, including emerging economies, has had major implications for the country, including its school system. The previously relatively stable and predictable, if unjust, school system needed radical change. In this paper, we report on how Organisation Development (OD) as an action research school change strategy was introduced to a school staff. The outcome has been a gradual change in the organisation culture of the school. This includes more collaborative decision-making, open communication, teacher leadership, increased enthusiasm among teachers, and an on-going process of incremental school change. We suggest that OD is a feasible change strategy for schools and school systems in emerging contexts of rapid and ongoing change in which schools are expected to take increasing responsibility for themselves.

Keywords: developing context, organisation change, organisation development, school culture, school improvement, survey-data-feedback

\section{Introduction}

After the national transition in 1994, South Africa was welcomed back into the international political and economic arena. Becoming part of the global community, including emerging economies, has had major implications for the country, including its school system. Schooling, more so in an emerging context, is regarded traditionally as the gateway to economic access and success (Maclean, 2001). Policy and structural change have been the 
name of the game. The previously relatively stable and predictable, if unjust, school system needed radical change. An inherited racially lopsided school system needed major restructuring organisationally and in terms of its financial allocations, resourcing, and peopling. However, as Bayeni (2014, p. 54) has concluded, "contrary to policy-makers' espoused policy intentions, policies seem not to have made any significant changes in school practice." International benchmarking tests (Mullis, Martin, Foy, \& Arora (2012a, 2012b) as well as local research (South African Government, 2013) reveal a school system in disarray; $80 \%$ percent of all schools in South Africa have been described as dysfunctional (Bloch, 2009). The vision of a socially just school system that would grant pathways to realising the benefits of South Africa's emerging economy and its international networks has become blurred. For example, a national census has revealed that skill levels among the youth are declining (Stats SA, cited in Merten, 2016).

In addition, following international trends, South Africa adopted a relatively self-managed school system according to the Department of Education (1996). Decision makers assumed that the capacity existed in schools to direct their own organisation destiny. However, being accustomed to depending on a top-down school bureaucracy, most South African school managers had little knowledge or experience of initiating school change. The situation was no different in school districts (McKinney, 2009). This is a challenge experienced across the board in developing and, in some cases, even developed contexts, as Glewwe and Kremer (2006) have reminded us.

In 1994, Davidoff, Kaplan, and Lazarus presented a paper at the Kenton 21 conference entitled "Organisation development: An argument for South African schools." The paper was subsequently published in the conference proceedings (Davidoff, Kaplan, \& Lazarus, 1995). It recounted an organisation development (OD) intervention in a Cape Town township school. In 1994, Clive Smith introduced a hands-on "Introduction to OD" module in both his bachelor of education honours and master's courses. Students in both courses took to OD like ducks to water. A number of former students have reported on facilitated OD interventions for their master's degrees.

As part of the post-1994 developing-a-democracy agenda, the new South African government's task team report, "Changing management to manage change" (Department of Education, 1996) put forward a vision for school transformation in the public school system. The report noted that "education ... transformation requires ... organisational development" (p.16). Teachers were to be change agents, embracing leadership and management responsibilities (Msila, 2008). Ironically, the missing ingredient was a process, such as OD, that could translate the task team's vision into reality.

This paper is an account of an ongoing OD intervention facilitated by Marion Mackinnon, one of Smith's former honours students. The intervention is a continuation of what began as an OD assignment. The argument for OD in South African schools still stands.

After an introduction to OD, including its theoretical underpinning, and the research design, the story of the intervention is recounted, in keeping with Wolcott's (1994) recommendation 
that in a descriptively oriented account the researcher " "tell the story" (p. 16). We conclude with learnings from this intervention.

\section{Organisation development}

While McGregor is credited with having coined the term "Organisation Development" in the 1950s (Weisbord, 2012), it was Lewin (1946) who had earlier conceived of a process-a portent of his classic dictum that "there is nothing so good as a practical theory" (Lewin 1951, p. 169)—of organisation participants looking at themselves in the mirror with a view to improving the way things are done, thereby enhancing their work satisfaction. OD emerged as part of what came to be called the human relations movement (Likert, 1967) in business and industry that was a reaction to the worker-as-machine view of organisations (Schmuck, Bell, \& Bell, 2012).

Lewin's OD work also marked the origin of the idea of a learning organisation (Weisbord, 2012) resurrected more recently by Senge (1990). It was also the origin of participatory action research (Cummings \& Worley, 2009). Indeed, the terms organisation development and action research are often used interchangeably (Gallant \& Rios, 2014; Senior, 2002). Or, as French and Bell (1999) viewed it, OD, as an approach to organisation change, adopts the action research methodology.

During the 60-odd years since OD was birthed it has morphed into its present form. Numerous theories and concepts from a range of disciplines, such as social-psychology, sociology, psychology, anthropology, and organisation and leadership (see Burnes \& Cooke (2012) for a succinct history of OD), have informed its theory and practice. OD has a rich heritage in the worlds of both business and schooling.

OD is a normative-re-educative (Chin \& Benne, 1976) or participative-cultural (Smith, 2003), approach to planned change, development, and transformation that focuses on the individual, group, and organisation. At its core, it entails participatory democratic practices in groups and organisations with a view to developing sustained spirals of learning and change (Smith \& Mackinnon, 2011).

According to Chin and Benne (1976), cultural change strategies have assumptions about human motivation different from those underlying traditional change strategies. A cultural change approach maintains that

patterns of action and practice are supported by sociocultural norms and by commitments on the part of the individual to these norms. . . Change in a pattern of practice or action, according to this view, will occur only as the persons involved are brought to change their normative orientations to old patterns and develop commitments to new ones. And changes in normative orientations involve changes in attitudes, values, skills, and significant relationships, not just changes in knowledge, information, or intellectual rationales for action and practice. (p. 23) 
Schmuck and Runkel (1994) describe OD as a

planned and sustained effort at system self-study and improvement, focusing on change in norms, structures, and procedures, using behavioral science concepts and methods. Organization development engages system members themselves in the active assessment, diagnosis, and transformation of their own organization. (p. 67)

Core values that inform the OD process include participative democracy, egalitarianism, a people orientation based on human need satisfaction (McClelland, 1961), an optimism that things can be better, the belief that individuals and groups can make a difference (see McGregor's theory Y view of organisation participants, cited in Weisbord, 2012), and transparency (Schmuck et al., 2012).

OD has distinguishing features and principles that are derived mostly from the behavioural sciences (French \& Bell, 1999). These include change readiness at individual (Weisbord, 2012), organisation (Schmuck et al., 2012) and system levels (Calkins, Guenther, Belfiore, \& Lash, 2007); participation of all those likely to be affected by the outcome of a process (Lewin, 1947b cited in Weisbord 2012); a future orientation (Weisbord, 2012); a systemic (French \& Bell, 1999) and cultural (Chin \& Benne, 1976) perspective that embraces both width and depth of change; and sustained change that becomes part of the organisation's culture or "what is going on here" (Wolcott, 1990, p. 32).

Lewin's work, according to Schein (1985), provides a change theory especially as it relates to the assumptions, principles, values, processes, and approaches to change set out above, that remains the benchmark for distinguishing authentic OD from other approaches to change, such as change management and training and human resource management (Burnes \& Cooke, 2012; Woodman, 2014). The core assumptions of Lewin's change theory are that effective and sustained change occurs through dialogue in groups that include all those likely to be affected by any change. Such dialogue facilitates a shared understanding of present conditions and agreement about desired changes. For Lewin (1946), the understanding and learning generated by this dialogical process was more important for the participants than any resultant change.

However, during the 1970s and 1980s, with the onset of modern globalisation, economic troubles, and rapid technological change, OD lost favour and alternative more businessresults rather than people-oriented change approaches, such as strategic change and change management, were proposed. Pettigrew (1985), for example, claimed that Lewin's modernistrational change thinking was outmoded and theoretically inadequate to account for a different cultural and historical context to his own. He argued that change approaches needed to take account of constructivist and post-modern ontologies and epistemologies. Pfeffer (1992, cited in Burnes, 2004a) believed that organisation change is more likely to be the outcome of competing power struggles where those with more power hold sway over those with less. In his view, change is unlikely to be the outcome of participative group processes. Collectively, these alternative change approaches were labelled as "emergent change" (Weick, 2000, p. 227). 
Nevertheless, these alternatives were, in turn, criticised for being helpful only for understanding but not changing organisations (Andriopolous \& Dawson, 2009). Despite Bradford and Burke's (2004, p. 370) suggestion that OD "lacks a central, agreed-upon theory of change — or even approach to change," Bullock and Batten (1985), in their review of over 30 planned change models along with Hendry (1996), found that Lewin's change theory remained as influential as ever. Hendry (1996, p. 624) commented,

Scratch any account of creating and managing change and the idea that change is a three-stage process which necessarily begins with a process of unfreezing will not be far below the surface. Indeed, it has been said that the whole theory of change is reducible to this one idea of Kurt Lewin's.

Burnes (2004b, p. 992) went so far as to suggest that critics of Lewin's planned change appear to have misread, "or perhaps even not read" his work.

Others (for example, Lambrechts, Grieten, Bouwen, \& Corthouts, 2009) have argued that Lewin's change process in which multiple perspectives are generated in dialogue, as reflected in Schein's (1988) process consultation for example, is an inherently social-constructionist approach. Similarly, Burnes (2011) has highlighted the connection between Lewin's Gestaltbased field theory and social constructionism. Wooten and White (1999) have shown that Lewin's change thinking aligns with post-modern organisation values, such as egalitarianism. Indeed, social constructionism can be seen as the ontological and epistemological foundation of Lewinian OD (Cummings \& Worley, 2009; Van Nistelrooij \& Sminia, 2010).

Finally, current influential change approaches, such as those of appreciative inquiry (Cooperrider \& Srivastva, 1987) and complexity theory (MacIntosh \& MacLean, 2001), are claimed by some to be new approaches to change, even incompatible with OD (see Burnes, 2004a). Others (for example, Oswick, 2009) argue that these are fresh manifestations of Lewin's original change thinking. In Burnes and Cook's (2012) view, since the 1990s the revival of OD's Lewinian heritage has promoted the development of theoretically convincing and practically sound change approaches. Although the efficacy of any change approach, including OD, is unconvincing, Robertson, Roberts and Porras's (1993) meta-analysis of OD interventions concluded that OD is a valid change approach.

As an aside, a substantial piece of detective work by Cummings, Bridgman, and Brown (2016) has found in Lewin's writing (Lewin, 1947a) evidence of his use of only the term "unfreezing." Subsequent scholars, Lippitt, Watson, Westley, and Spalding (1958) and Schein (1961) in particular, added or invented the "moving" and "refreezing" phases neither of which appears anywhere in Lewin's writing. In fact, "refreezing" stands in stark contrast to his view of life as being dynamic and a sphere in which groups constantly adapt to changing conditions and contexts (Cummings et al., 2016). In this study, we refer to sustained change, rather than to "refreezing." 


\section{How does OD work?}

We follow Burke's (1994) stages of an OD process. These stages, which can be divided into two broad phases, will become evident in the following account of the intervention. The first phase is the "Start up" that consists of the initiation and diagnosis. The second phase, problem-solving, that consists of change interventions, typically follows the diagnosis.

An OD process is ideally initiated by prospective participants, whether an organisation or group in an organisation, who recognise an opportunity, challenge, or need. In the intervention, which is the subject of this article, Mackinnon, a staff member on the management committee of the school involved, initiated the process.

During the start-up phase, the facilitators offer a "What is OD and how does it work?" workshop. The purpose of the workshop is to ensure that the prospective participants become familiar with OD values and principles and that they know what OD entails, so that they can take an informed decision as to whether to participate or not, thereby meeting the ethical criterion of informed consent (Busher \& James, 2007). Most important is that participants understand that they are the experts and that they will drive the process. The facilitators are there to serve by way of offering a process. The workshop is also intended to raise levels of readiness by helping the prospective participants develop some trust and confidence in the process and by engendering a belief that they can make a difference in their own organisation should they wish to do so.

A diagnosis will typically begin with participants, supported by the facilitators, identifying the issues and/or possibilities that they think need attention or that they want to do something about. After prioritising these issues and possibilities, they will be diagnosed, normally using a gap analysis approach (French \& Bell, 1999; Schmuck et al., 2012). The data upon which the diagnosis is based may be generated by interviews, questionnaires, observation, workshopping, journaling etc. The facilitation team will then analyse and feed the data back to the participants. The feedback offers the participants an opportunity to verify the accuracy of the data and its interpretation and helps participants to "unfreeze" (Lewin, 1947a, p. 36) by releasing them to speak about what has often hitherto been unspeakable. The feedback also provides a potential agenda for future action and energises participants as they develop a sense of hope in future possibilities. The diagnosis is typically referred to as a survey-datafeedback (SDF) intervention and is the most common and successful initial intervention in an ongoing OD intervention (Cummings \& Worley, 2009; Roodt, 2008; Schmuck et al., 2012). In Woodman's (2014, p. 470) view, "diagnosis might be considered as the starting point to all organizational change."

This second or change phase in the OD process may consist of individual, group, and organisation-wide activities that can go on for months, or even years, in the case of fundamental and complex change interventions. In the case of the intervention that is the subject of this study, the intervention has entered this second phase and, at the time of writing, was in its 16th month. 
These phases are best illustrated in Figure 1. "Identification of a need for change to exploration of the data by client group" is the start-up phase. "Action planning by client group to reflection and evaluation by client group" and potential further spirals of diagnosis and action constitute the second or action phase of an ongoing OD intervention.

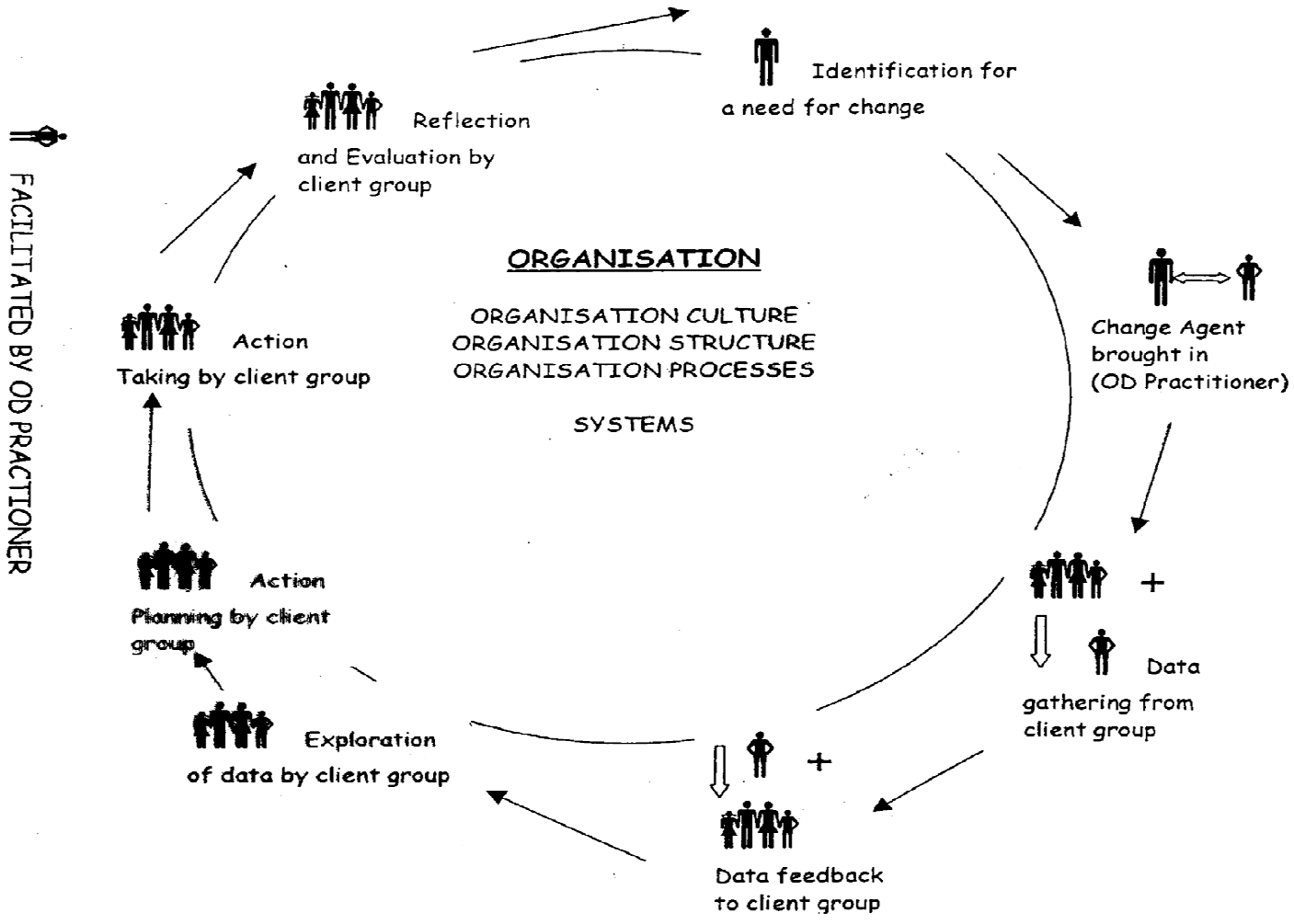

Figure 1: The organisation development cycle

\section{Research design}

OD adopts a participatory action research (PAR) design as its method (French \& Bell, 1999; Lewin, 1947b; Schmuck et al., 2012). Indeed, the PAR process is the method (Kidd \& Kral, 2005). Besides being located in the social constructionist paradigm, as noted in the review of the literature above, PAR often shares the ontological and epistemological assumptions of the critical research paradigm (Baum, MacDougall, \& Smith, 2006; Guba \& Lincoln 1994). Its concern in OD is to provide a process that enables organisation participants to become aware of oppressive and/or dysfunctional organisation cultures, structures, processes, and power relations with a view to transforming them into more just, equitable (Kemmis \& McTaggart, 2008), dignified, meaningful (Weisbord, 2012) and humanly satisfying arrangements.

The intervention site is an independent boys' school. It follows the structure of traditional boys' schools offering a holistic education that includes academics, religion, sport, and culture in the programme. The school caters for over 1,200 boys in three sections: college, primary, and elementary. Each section has its own head who is an executive committee 
member. An executive head leads the executive committee. The elementary section, where the intervention was carried out, caters for 400 boys with a staff complement of 30 including a 7-member management committee, of which Mackinnon at the time of writing was the member responsible for leading the school's academic programme. The school attracts middle- to upper-class families.

Having approached the elementary school principal for approval to conduct her honours OD assignment in the foundation phase of the elementary school, Mackinnon was given the goahead. She followed the initiation process in the start-up phase, as described above. The "What is OD?" workshop generated a good deal of animated discussion, the outcome of which was an agreement to participate in a SDF diagnosis. Following Wolcott's (1994) guidance on the writing of a descriptive qualitative account, the story of the process unfolds in the next section.

Besides the formal data gathering by way of interviews and questionnaires for the diagnosis itself, Mackinnon generated data about the diagnosis through participating in group discussions, activity debriefs that took the form of group reflections at the end of an activity or session, and informal conversations with participants during the process, including during sessions and breaks, and between sessions; informal observation of participant behaviour during and between sessions; and documents, such as newsprint and records of decisions about new ways of doing things, generated by the process. Participants, both those who volunteered to be part of the facilitating team and as a group in plenary sessions, analysed and interpreted the data. This process provided a springboard for each succeeding step in the unfolding intervention.

Action research used in organisation development is based mostly on collaboration between an OD researcher and a client during which they collaborate in diagnosing client-identified organisation issues and then cogenerate actionable interventions in terms of quality criteria of rigour, reflectivity, and relevance (Coghlan \& Shani, 2014). Employing Lather's (1986, p. 78) notion of "catalytic validity," research quality was assured as participants generated and validated their own data and processes as the intervention took its course and as they became excited about the changes they were bringing about through their own agency. Evidence of these changes follows in the account of the intervention below, in Table 2, in particular.

Through its Lewinian roots in the scholarship of practice, OD has the capacity to bridge the rigour-relevance, theory-practice debates that beset contemporary organisation studies. Accordingly, action research is not only a methodology and a set of tools but is also a theory of social science.

The honours assignment has ethical clearance from the relevant university ethics committee and was approved by the school's management. Following O'Leary (2004), pseudonyms are used for the names of people and places in order to preserve confidentiality and protect the identity of those concerned. 


\section{The intervention}

\section{The "What is OD?" workshop}

Junior School regards itself as a good elementary school. The parents and general community regard it as a good school. However, early in the OD intervention, during the "What is OD?" workshop debrief at the end of the workshop, the principal reflected,

Understanding organisation development has opened my eyes to so many aspects within the school which had reached a level of complacency, where the assumption was that things were running smoothly and there was no need to introduce organisational change or explore the opinions of its staff.

This could be described therefore, as a "cruising" school (Stoll \& Fink, cited in Stoll, 2003, p. 100).

After explaining briefly to the principal what OD is and how it works, and the principal having given the go-ahead and his support, Mackinnon then requested that she facilitate a "What is OD and how does it work?" workshop with all the likely participants in the intervention, in this case the school's 16 Grade R, 1, 2, and 3 (foundation phase) teachers. Academic support teachers and the librarian along with subject teachers in religious education, music, and computers from other grades who were involved with the foundation phase were also invited to participate and were distributed among the teachers of the four grades. They agreed that the traditional staff day held the day before the start of a new term be devoted to the workshop. Two key OD principles, gatekeeper support (French \& Bell, 1999), in this case the principal, and the invitation of all those likely to be affected by the outcome of an OD process to participate in that process (Lewin, 1947b), were adhered to.

After a brief introduction concerning its purpose, the three-hour workshop began with a crossword puzzle ice-breaker which was followed by a group activity during which groups identified scenarios at school that, similar to those revealed in the ice-breaker, reflected unequal opportunities for influence, achievement, and recognition, all of which triggered negative feelings of tension, stress, and demoralisation. A lot of open and honest discussion followed. Many teachers admitted that they related to those feelings but thought they were the only ones experiencing them. This is a form of ignorance that results from a lack of open communication (Schmuck et al., 2012). The discussion proved to be ground breaking in initiating what has become a new culture of open communication that was consolidated as the OD intervention proper unfolded. This was an important development since effective communication that includes openness and honesty, is the foundation of effective organisation life (Schmuck et al., 2012).

OD was then introduced. This included a brief history, an outline of the core values, assumptions, and principles, and an account of how it works in relation to the participatory action research methodology and typical designs, including SDF. 
The workshop included an activity on the concept of "change" during which a variety of quotations was used to generate a discussion about organisation change. The purpose was to illustrate that change is not just about new knowledge and approaches, but also about changed attitudes, values, and relationships (Fullan, 2007) and, most of all, improvement.

In another activity, the staff were shown a number of abstract graphics to demonstrate how people have different perceptions of the same reality to underscore the importance of validating one another's experiences and perceptions of the respective organisation realities of others.

The staff were then invited to consider what aspects of their school they thought might benefit from an OD intervention. Because the workshop had created an atmosphere of trust as insisted upon by Schmuck et al. (2012) and the readiness for change advised by Zayim and Kondakci (2015), teachers felt sufficiently bold to write down their suggestions on the post-it notes provided. These were placed on a white board. The staff then grouped these into themes, and they were subsequently colour coded for ease of identification. The three key themes identified based on the number of responses were:

a. How can teachers be best supported with the introduction of new teaching methodologies?

b. A need for class assistants to optimise group-work activities and the reading programme.

c. A need to review the policy and approach to discipline and school rules to ensure that there is consistency among all staff on how these are implemented.

The workshop concluded with teachers being asked to complete an anonymous evaluation of the workshop that included having them indicate whether they would like to participate in a SDF intervention. The results of the survey indicated that the staff was unanimously in favour of such an intervention. Typical feedback comments included

- Refreshing, feels like we are on the same team

- Promotes interaction

- Thought provoking and fun to chat together

- Very interesting and positive to exchange views

- Enlightening and non-threatening

- Novel to discuss our solutions to problems

- Working towards a common goal

- Being able to express how I feel

- Learning about the views of others [and] realising I'm not the only person with certain issues

The workshop had raised the staff's level of readiness to engage in the OD intervention. It was now important not to lose the momentum and to commence with the intervention. This was done at an informal feedback meeting at break the day after the workshop. 


\section{The SDF intervention}

At the feedback meeting, all staff members were given a list of the intervention suggestions that had been clustered and colour coded according to the themes. The most pressing issue identified was the introduction of new teaching approaches. When the teachers saw this, there was virtually immediate consensus demonstrated by a spontaneous nodding of heads and a chorus of verbal affirmation as individual teachers realised that they were not alone in the area they had identified as a source of stress and as needing change. The school had embarked on a professional development programme that was clearly overwhelming the staff. Teachers felt that they were not adequately equipped, trained, or supported to implement the new programme effectively.

During the "What is OD?" workshop, Mackinnon had explained that a process of datagathering would follow the identification of an issue or issues for diagnosis, in order to more fully understand the nature of the issue and what changes were desired. This would be handled by a facilitation team comprised of staff volunteers and herself, thereby making the process collaborative, as well as developing OD facilitation capacity in others. This "empowering" (Kolb \& Kolb, 2005, p. 208) of participants is another OD principle. Three staff members, with from three to thirty years' teaching experience, offered to join the team. This added credibility to the process. The facilitation team agreed on how data would be generated, and participated in the focus group sessions, including the agreement of group norms, listing the questions to be discussed, and determining the group processes such as having a scribe record discussions and observations on flipcharts. The analysis and coding of diagnostic data was done collaboratively by the facilitation team. The strategies were agreed upon by all the participants following the data analysis. The facilitating team then designed the cumulative data generation process set out below. Again, in order to maintain momentum, the data generation process commenced the following week.

\section{Survey}

The participants decided to make the initial survey anonymous so that they could express their opinions freely. This data would then be explored further in the focus groups to follow.

The outcome of the survey was that the teachers were generally open to change and welcomed the new teaching approaches in particular but felt quite overwhelmed by the new demands placed on them. They had many suggestions for improvement. What they wanted most was a forum in which to express their ideas, where they knew they were being heard, and where they could make a significant direct contribution, rather than through representatives.

\section{Focus groups}

To follow up the survey data, the staff formed, for the first time, two cross-grade focus groups that met simultaneously in the week following the survey. Participants in both groups agreed that it was an effective forum in which to express ideas, and common ground was 
established. Rich and comprehensive data was gathered, and, for the first time, teachers expressed their frustrations openly and offered valuable ideas for resolving problems and challenging the way things were being done. They also realised that, collectively, the staff has a wealth of teaching expertise that should be shared.

\section{Individual interviews}

During the week following the focus group interviews, each of the four members of the facilitating team adopted one of the four grades and interviewed each teacher in that grade to further explore the focus group data. There was strong confirmation for the prioritisation of teaching and learning since staff meetings focus generally on operational and policy matters and the full staff group was too large for collaborative interaction. There was also unanimity that teachers wanted to meet regularly across grades to share ideas and best teaching practices that could be implemented by all.

\section{Feedback}

The next step in the SDF process was the feedback of the data generated from the survey, focus groups, and individual interviews to the full staff. The data was analysed by the facilitating team and fed back two weeks after the data generation process had been completed.

The data was fed back in the format reflected on the chart below.

Table 1: Data fed back to participants

\section{WANT AND HAVE}

We work well together as a team and have support within the grade

Innovations and new methodologies are encouraged

Good communication structure and open door policy

\section{WANT BUT DON'T HAVE}

More support with new teaching approaches

Time management

More resources and sharing of existing presentations, games, ideas

Opportunity for individuals to have more of a voice and influence in teaching matters

\section{DON'T WANT BUT HAVE}

DON'T WANT AND DON'T HAVE

Feelings of inadequacy and overwhelmed with new teaching approaches

Teachers have mixed perceptions of their colleagues' response toward changing teaching approaches

Staff meetings not conducive to developing teaching and learning 
Having verified and explored the data, the staff decided to proceed with the second phase of the intervention - change. The staff agreed on a change agenda derived from the above feedback and that the action planning, implementation, and review would be facilitated and led by the two focus groups. The feedback had gone some way toward effecting the "unfreezing" stage of Lewin's (1958) change model. The staff's realisation that they had shared feelings of inadequacy and of feeling overwhelmed by the new teaching approaches, that they were anxious about not being able to meet the expectations (that they supported) of the new teaching approaches, and the psychological safety they enjoyed in their work environment provided sufficient motivation for them to engage in a change process-see Schein's (1992) elaboration of Lewin's “unfreezing."

\section{Second phase: Change and learning}

\section{Process related changes}

Teachers verbalised concerns during the SDF that they did not know how to implement change. Because OD is a planned change approach, it provided an opportunity to address this gap (French \& Bell, 1999) between the desire for change and actual change, with a structured change process. After they had experienced the focus groups during the data generation, the teachers suggested focus groups as a vehicle for this. All commented on how productive the group discussions had been.

The staff agreed, on the basis of their focus group experience, that smaller groups were more conducive to productive discussion. They retained their two cross-grade groups and meet at a scheduled time on Wednesdays every two to three weeks.

Leadership roles within the focus groups, such as agenda builder, recorder, time keeper, process observer, follow-upper, etc (Schmuck et al., 2012) were agreed upon. A workshop was held on running effective meetings to maximise the benefits of leadership roles in meetings. These roles were rotated, and a staff member drew up a grid to manage this.

Staff agreed that all meetings would conclude with a specific way forward and the followupper role was to ensure that these were actioned. The reporters gave feedback on the respective focus groups' work at the general staff meeting, for communication and ratification. Where appropriate, school-wide decisions were taken at the staff meeting.

In a survey conducted at the end of the intervention reported on here, a participant observed, "Focus groups have become part of the culture of the school. Structures are in place to ensure the continuity of the change process we have embarked upon. It's now 'the way we do things around here.",

\section{Teaching and learning related changes}

The following are the main changes that have been introduced and sustained. 
Table 2: Changes introduced and sustained by the OD intervention participants

\begin{tabular}{|c|c|}
\hline $\begin{array}{l}\text { Teaching activities } \\
\text { are less paper based } \\
\text { and more } \\
\text { experiential and } \\
\text { collaborative. }\end{array}$ & $\begin{array}{l}\text { Staff exposed to strategies to add to their toolbox that enable pupils to } \\
\text { demonstrate their learning in a variety of practical ways rather than being } \\
\text { worksheet bound. 21st century learning skills (creativity, collaboration, } \\
\text { communication, critical thinking); Harvard thinking routines; visible } \\
\text { thinking; technology; inquiry-based learning; learning through play etc. } \\
\text { introduced. A dramatic reduction in printing costs. Teachers frequently } \\
\text { invite the principal to view lessons that use these new strategies and } \\
\text { equipment. } \\
\text { Bought new desks with a whiteboard surface (write on/wipe off) so that the } \\
\text { boys can make their thinking visible in a variety of ways. The new desks } \\
\text { have enabled a flexible classroom layout and also lend themselves to } \\
\text { collaborative work. A lot more game-based and inquiry-based learning has } \\
\text { been introduced. Investment in educational equipment to support all this. } \\
\text { Budget allocations are now transparent. All staff have a say in identifying } \\
\text { resource needs. }\end{array}$ \\
\hline $\begin{array}{l}\text { There are now } \\
\text { coordinated work, } \\
\text { including } \\
\text { assessment, schemes } \\
\text { that ensure a smooth } \\
\text { progression from } \\
\text { one grade to the } \\
\text { next. }\end{array}$ & $\begin{array}{l}\text { A detailed work scheme that encompasses all grades was created } \\
\text { collaboratively and is easily accessible on the shared drive. } \\
\text { The staff meeting format has changed from sitting around a boardroom table } \\
\text { with a chairperson leading to sitting in groups in the library. Even though } \\
\text { teachers are seated in little chairs the culture has changed to collaborative } \\
\text { discussions and the sharing of ideas and strategies. Grouping is fluid with a } \\
\text { blend of different grades rather than teachers from individual grades sticking } \\
\text { together. }\end{array}$ \\
\hline $\begin{array}{l}\text { There have been } \\
\text { presentations by } \\
\text { teachers who have } \\
\text { developed areas of } \\
\text { expertise, such as } \\
\text { co-operative } \\
\text { learning, Collaborate } \\
\text { Learning Encounter } \\
\text { (CLE) and using a } \\
\text { data projector. }\end{array}$ & $\begin{array}{l}\text { The school has a generous professional development budget. Teachers are } \\
\text { able to attend courses and then share their learning with their colleagues. } \\
\text { Professional development sessions are held every second Wednesday } \\
\text { afternoon. These workshops are increasingly being led by staff who have } \\
\text { successfully implemented new strategies. A big cultural change is } \\
\text { acknowledging the expertise of teachers. Teachers teaching teachers has } \\
\text { been well-received and has become a norm. }\end{array}$ \\
\hline $\begin{array}{l}\text { Reduction in routine } \\
\text { administrative staff } \\
\text { meeting time. More } \\
\text { time devoted to } \\
\text { professional } \\
\text { development. }\end{array}$ & $\begin{array}{l}\text { TeamTime is held each week at break. The agenda is placed on a shared } \\
\text { Google document so that it can be populated by any member of staff. This } \\
\text { informal staffroom format allows open discussion and staff to contribute } \\
\text { their ideas. This collaborative approach has resulted in richer decisions and } \\
\text { opportunities for staff to be heard and to have their ideas adopted. } \\
\text { As an aside, this has resulted in fewer and shorter general staff meetings and } \\
\text { more time for professional development. Operational issues are } \\
\text { communicated using email via a daily message and, where necessary, } \\
\text { discussed at TeamTime. }\end{array}$ \\
\hline
\end{tabular}

The changes have enhanced teaching and learning. The boys participate more actively in their learning and are able to apply a wider range of thinking strategies to solve problems. Teachers have had to step back from doing all the talking and allow more inquiry from the 
learners. A simple technique like Think Pair Share "creates the platform for all to think and express opinions rather than only those eager kids who put up their hands just to be heard, but who have not necessarily thought deeply about the topic."

The outcomes of the cross-grade focus group meetings have been beneficial since teachers have become aware of the wealth of expertise among themselves (see Weisbord, 2012). They have been able to learn from the experiences and best practices of their colleagues and have adopted an attitude and intention of being continual learners. In addition, the staff have become more unified through the process of collaboration, and the culture of support and interdependence between grades.

\section{Leadership and management reconceptualised as facilitation}

The head of the elementary school commented,

I adopted an attitude of working with the group as a co-learner. I also acknowledge the achievements made both on an individual and group basis. I have become open to accepting ideas that have emerged from group consensus by acknowledging that teachers are best placed to make decisions that affect them and that they are the experts and have the capacity to make a difference. This process has achieved buy-in and empowered the teachers as they have committed to the plans they helped create. Transformation is impossible if it is the sole responsibility of the principal.

The principal also actively supports the process and the shared vision. She participates in focus group sessions and presentations and, where possible, approves the purchase of materials that could further enhance the strategies teachers want to implement.

\section{The human factor: People first}

Putting people first now informs all decisions, policies, and interventions. Because OD is grounded in human need theory (McClelland, 1961), the school's formal leadership is becoming increasingly mindful of these needs and how they can be satisfied. According to the principal, "I have been guided by McClelland's human need satisfaction theory."

She went on to explain,

In our school context, these needs can be characterised by the wish to work collectively and take responsibility for innovations and solutions. OD recognises that people are best placed to solve their own problems. This has been demonstrated in the way that teachers put systems in place to address the areas they identified as needing change and have put practical strategies in place. This forum (focus groups) for sharing expertise has satisfied the need for achievement and recognition and enhanced their teaching experience.

The fact that teachers were able to influence others and see their suggestions being used in classrooms, or turned into action plans that have been implemented, has become a strong 
motivating factor. There has also been an increased sense of collaboration and belonging as a culture of mutual support for one another has emerged, and this confirms Weisbord's observation that "people benefit most from talking with one another and deciding what to do" (2012, p. 236).

The principal also noted,

I have observed how teachers have flourished when they know their insight is valued and when they are entrusted with areas of responsibility. I have become profoundly aware of how much teachers want to be able to express their views openly and have influence in decisions that affect them and the running of the school. I have found that by addressing those human needs, the task of teaching can stretch individual's potential and raise the level of job satisfaction making it rich and rewarding.

What also emerged was that there were teachers who had been feeling inadequate and who thought they were alone in their inadequacies. The openness in the focus groups has enabled teachers to confess, as it were, their feelings and anxieties, and to support one another in their learning and growth.

The principal concluded by saying,

Our school has entered into a phase of becoming a learning organisation with structures to enable ongoing development. These shifts in focus have initiated transformational change resulting in a more empowered staff as well as school improvement. Systems are in place for the continuous improvement of teaching as well as more alignment between goals and principles.

\section{Conclusion}

Over the past 25 years, almost without fail, when students have introduced OD in their workplace there has been a great deal of excitement and optimism at how different the OD approach to change is, as well as the power and possibilities of the process. For many, it has been the first time ordinary organisation members have been able to initiate, participate in, and even lead school change. However, the converse of this has been that formal leaders and managers often feel threatened by having to share and suspend their power, thereby proving to be ineffective facilitators of change (Msila, 2011). This has been a widespread finding in OD research in developing contexts (Golembiewski, 1991; Smith, 1995). Hofstede (1991) has found that cultural dimensions, such as power-distance and uncertainty avoidance, influence organisations' perception of and approach to organisation change. This has often derailed what has been an otherwise promising process. A second typical outcome my students have experienced in their OD SDF assignment interventions is that participants grow weary of the time and effort required to take responsibility for their own organisation destiny and revert to a default position of dependence on the education system hierarchy to tell them what to do. Participants seem to have a weak sense of agency. Mjoli (1987) ascribed this kind of thinking to one with an external locus of control where one believes that one's fate is determined by 
outside forces over which one has no control. These are issues requiring further research in SA.

The principal concluded,

This OD intervention has forced me to look closely at my own style of management as well as the roles, culture and needs of the people within the organisation. It has meant acknowledging that the climate was not as content as it appeared, nor as democratic as it espoused to be. Most of all, I realised that we have a talented staff who have an enormous amount to contribute, and their need to have some influence was not being met, and there was no forum for them to express their ideas and frustrations, or to promote their innovativeness.

The jury is still out on much of what the literature considers to be barriers to successful OD practice, in developing contexts in particular. This account may be considered a contribution to the OD literature in South Africa that offers a pointer to further possibilities for OD practice and research in this country.

Emerging economies, that are mostly moving in the direction of entrepreneurialism, selfmanagement, and personal agency, as well as increasingly democratic decision-making structures and processes, require leaders with change process competence (Hoskisson, Eden, Lau, \& Wright, 2000). The Department of Education (1999) identified a lack of leadership and management capacity in the South African school system as the most pressing issue facing our schools. If there is to be significant and meaningful change in our schools, systemwide leadership and management needs urgent attention. Education leadership and management development "is the key to transformation in education" (Welton, 2001, p. 175) and "a key need is to understand how to manage change" (p. 182). OD offers such a process.

Lewin's (1992) approach to problem solving and change was one of doing by learning and learning by doing. In other words, for him we need to understand "theory in practice" and we need to "practise theory" (Lewin, 1992, p. 8; see also Weisbord, 2012). It was action based upon research. What was unique was that this research was conducted by the participants upon themselves, their own work practices, experiences, and perceptions. He urged people to reflect critically on taken-for-granted assumptions, use common sense. and find out what works by practising it. He offered a theory for turning research into action. "Lewin wed scientific thinking to democratic values and gave birth to participative management" (Weisbord 2012, p. 72) and democratic social change. This is what Mackinnon is doing.

\section{References}

Andriopoulos, C., \& Dawson, P. (2009). Managing change, creativity and innovation. London, UK: Sage. 
Baum, F., MacDougall, C., \& Smith, D. (2006). Participatory action research. Journal of Epidemiology \& Community Health, 60(10), 854-857. https://doi.org/10.1136/jech.2004.028662

Bayeni, S. (2014). Principals' mediation in policy implementation: A case study of six secondary schools (Unpublished doctoral dissertation). University of KwaZulu-Natal, Pietermaritzburg, RSA.

Bloch, G. (2009). The toxic mix: What's wrong with South Africa's schools and how to fix it. Cape Town, RSA: Tafelberg.

Bradford, D., \& Burke, W. (2004). Introduction: Is OD in crisis? Journal of Applied Behavioral Science, 40(4), 369-373. https://doi.org/10.1177/0021886304270821

Bullock, R., \& Batten, D. (1985). It's just a phase we're going through: A review and synthesis of OD phase analysis. Group and Organization Studies, 10(4), 383-412. https://doi.org/10.1177/105960118501000403

Burke, W. (1994). Diagnosis for organizational change: Methods and models. New York, NY: Guildford.

Burnes, B. (2004a). Kurt Lewin and complexity theories: Back to the future? Journal of Change Management, 4(4), 309-325. https://doi.org/10.1080/1469701042000303811

Burnes, B. (2004b). Kurt Lewin and the planned approach to change: A re-appraisal. Journal of Management Studies, 41(6), 977-1002. https://doi.org/10.1111/j.14676486.2004.00463.x

Burnes, B. (2011). Field theory of learning. In N. Seel (Ed.), Encyclopedia of the sciences of learning (pp. 1395-1429). New York, NY: Springer Science.

Burnes, B., \& Cooke, B. (2012). The past, present and future of organization development: Taking the long view. Human Relations, 65(11), 1395-1429. https://doi.org/ $10.1177 / 0018726712450058$

Busher, H., \& James, N. (2007). Ethics of research in education. In A. Briggs \& M. Coleman (Eds.), Research methods in educational leadership and management (2nd ed., pp. 106-122). Thousand Oaks, CA: Sage.

Calkins, A., Guenther, W., Belfiore, G., \& Lash, D. (2007). The turnaround challenge: Why America's best opportunity to dramatically improve student achievement lies in our worst-performing schools. New research, recommendations, and a partnership framework for states and school districts. Boston, MA: Mass Insight Education and Research Institute. 
Chin, R., \& Benne, K. (1976). General strategies for effecting changes in human systems. In W. Bennis, K. Benne, R. Chin, \& K. Corey (Eds.), The planning of change (3rd ed., pp. 22-45). New York, NY: Holt, Rinehart \& Winston.

Coghlan, D., \& Shani, A. (2014). Creating action research quality in organization development: Rigorous, reflective and relevant. Systemic Practice and Action Research, 27(6), 523-536. https://doi.org/ 10.1007/s11213-013-9311-y

Cooperrider, D., \& Srivastva, S. (1987). Appreciative inquiry in organizational life. In R. Woodman \& W. Pasmore (Eds.), Research in organizational change and development (pp. 129-169). Greenwich, CT: JAI Press.

Cummings, T., \& Worley, C. (2009). Organization development \& change (9th ed.). Mason, $\mathrm{OH}$ : South-Western.

Cummings, S., Bridgman, T., \& Brown, K. (2016). Unfreezing change as three steps: Rethinking Kurt Lewin's legacy for change management. Human Relations, 69(1), 33-60. https://doi.org/ 10.1177/0018726715577707

Davidoff, S., Kaplan, A., \& Lazarus, S. (1994, October). Organisation development: An argument for South African schools. Paper presented at the Kenton 21 Conference, Grahamstown, RSA.

Davidoff, S., Kaplan, A., \& Lazarus, S. (1995). Organisation development: An argument for South African schools. In G. Kruss \& H. Jacklin (Eds.), Realising change: Education policy research-Kenton 1994 (pp. 1701-1782). Cape Town, RSA: Juta.

Department of Education. (1996). Changing management to manage change: Report of the task team on education management development. Pretoria, RSA: Author.

Department of Education (National Youth Commission). (1999). Joint framework document: "Tirisano": Towards an intervention strategy to address youth violence in schools. Pretoria, RSA: Author.

French, W., \& Bell, C. (1999). Organization development: Behavioral science interventions for organization improvement (6th ed). Englewood Cliffs, NJ: Prentice Hall.

Fullan, M. (2007). The new meaning of educational change (4th ed.). New York, NY: Teachers College.

Gallant, S., \& Rios, D. (2014). The organizational development (OD) consulting process. In B. Jones \& M. Brazzel (Eds.), The NTL handbook of organizational development and change (2nd ed., pp. 153-174). San Francisco, CA: Wiley.

Glewwe, P., \& Kremer, M. (2006). Schools, teachers, and education outcomes in developing countries. Handbook of the Economics of Education, 2, 945-1017. https://doi.org/10.1016/S1574-0692(06)02016-2 
Golembiewski, R. (1991). OD applications in developmental settings: Four perspectives on action research in an important locus. Research in the Sociology of Organizations, 9, 201-263. https://doi.org/10.1080/09585199100000050

Guba, E., \& Lincoln, Y. (1994). Competing paradigms in qualitative research. In N. Denzin \& Y. Lincoln (Eds.), Handbook of qualitative research (pp. 105-117). Thousand Oaks, CA: Sage.

Hendry, C. (1996). Understanding and creating whole organizational change through learning theory. Human Relations, 49(5), 621-641. https://doi.org/ $10.1177 / 001872679604900505$

Hofstede, G. (1991). Cultures and organizations: Software of the mind. New York, NY: McGraw-Hill.

Hoskisson, R., Eden, L., Lau, C., \& Wright, M. (2000). Strategy in emerging economies. Academy of Management Journal, 43(3), 249-267. https://doi.org/ $10.5465 / 1556394$

Kemmis, S., \& McTaggart, R. (2008). Participatory action research: Communicative action and the public sphere. In N. Denzin \& Y. Lincoln (Eds.), Strategies of qualitative inquiry (3rd ed., pp. 271-330). Thousand Oaks, CA: Sage.

Kidd, S., \& Kral, M. (2005). Practicing participatory action research. Journal of Counseling Psychology, 52(2), 187-195. https://doi.org/10.1037/0022-0167.52.2.187

Kolb, A., \& Kolb. D. (2005). Learning styles and learning spaces: Enhancing experiential learning in higher education. Academy of Management Learning \& Education, 4(2), 193-212. https://doi.org/ 10.5465/amle.2005.17268566

Lambrechts, F., Grieten, S., Bouwen, R., \& Corthouts, F. (2009). Process consultation revisited: Taking a relational practice perspective. Journal of Applied Behavioral Science, 45(1), 39-58. https://doi.org/ 10.1177/0021886308326563

Lather, P. (1986). Research as praxis. Harvard Educational Review, 56, 257-277. https://doi.org/10.17763/haer.56.3.bj2h231877069482

Lewin, K. (1946). Research on minority problems. The Technology Review, 48, 163-190. https://doi.org/10.1111/j.1540-4560.1946.tb02295.x

Lewin, K. (1947a). Frontiers in group dynamics: Concept, method and reality in social science; equilibrium and social change. Human Relations, 1(1), 5-41. https://doi.org/ $10.1177 / 001872674700100103$

Lewin, K. (1947b). Frontiers in group dynamics 2: Channels of group life—social planning and action research. Human Relations, 1, 143-153. https://doi.org/ $10.1177 / 001872674700100201$ 
Lewin, K. (1951). Problems of research in social psychology. In D. Cartwright (Ed.), Field theory in social science: Selected theoretical papers (pp. 155-169). Westport, CT: Greenwood.

Lewin, K. (1958). Group decision and social change. In T. Newcomb \& E. Hartley (Eds.), Readings in social psychology (pp. 197-211). New York, NY: Harper \& Row.

Lewin, M. (1992). The impact of Kurt Lewin's life on the place of social issues in his work. Journal of Social Issues, 48, 3-13. https://doi.org/10.1111/j.15404560.1992.tb00880.x

Likert, R. (1967). The human organization: Its management and value. New York, NY: McGraw-Hill.

Lippitt, R., Watson, J., Westley, B., \& Spalding, W. (1958). The dynamics of planned change: A comparative study of principles and techniques. New York, NY: Harcourt Brace.

MacIntosh, R., \& MacLean, D. (2001). Conditioned emergence: Researching change and changing research. International Journal of Operations and Production Management, 21(10), 1343-1357. https://doi.org/10.1108/EUM0000000005973

Maclean, R. (2001). Overview: Secondary education at the crossroads. Prospects, 31(1), 3945. https://doi.org/10.1007/BF03220048

McClelland, D. (1961). The achieving society. New York, NY: Wiley.

McKinney, C. (2009). The role of districts in the South African schooling system: A literature review. Retrieved from http://www.hsrcpublishers.ac.za/full_title_info.asp?id=1937.

Merten, M. (2016, April 19). The great reversal: Stats SA claims black youth are less skilled than their parents. Daily Maverick, p. 18.

Mjoli, Q. (1987). The role of the psychologist in culturally diverse Southern Africa. Development Southern Africa, 4, 7-20. https://doi.org/10.1080/03768358708439291

Msila, V. (2008). Ubuntu and school leadership. Journal of Education, 44, 67-84.

Msila, V. (2011). School management and the struggle for effective schools. Africa Education Review, 8(3), 434-449. https://doi.org/10.1080/18146627.2011.618650

Mullis, I., Martin, M., Foy, P., \& Arora, A. (2012a). TIMSS 2011 international results in mathematics. Amsterdam, NL: International Association for the Evaluation of Educational Achievement. 
Mullis, I., Martin, M., Foy, P., \& Drucker, K. (2012b). PIRLS 2011 international results in reading. Amsterdam, NL: International Association for the Evaluation of Educational Achievement.

O'Leary, Z. (2004). The essential guide to doing research. Thousand Oaks, CA: Sage.

Oswick, C. (2009). Revisioning or re-versioning? A commentary on diagnostic and dialogic forms of organization development. Journal of Applied Behavioral Science, 45(3), 369-374. https://doi.org/10.1177/0021886309338687

Pettigrew, A. (1985). The awakening giant: Continuity and change in ICI. Oxford, UK: Blackwell.

Robertson, P., Roberts, D., \& Porras, J. (1993). Dynamics of planned organizational change: Assessing empirical support for a theoretical model. Academy of Management Journal, 36(3), 619-634. https://doi.org/10.5465/256595

Roodt, G. (2008). Survey research and data feedback. In C. van Tonder \& G. Roodt (Eds.), Organisation development: Theory and practice (pp. 251-268). Pretoria, RSA: van Schaik.

Schein, E. (1961). Management development as a process of influence. Industrial Management Review, 2(2), 59-77.

Schein, E. (1985). Organizational culture and leadership. San Francisco, CA: Jossey-Bass.

Schein, E. (1988). Process consultation (vol. 1): Its role in organization development (2nd ed.). Reading, MA: Addison Wesley.

Schein, E. (1992). Organizational culture and leadership (2nd ed.). San Francisco, CA: Jossey-Bass.

Schmuck, R., \& Runkel, P. (1994). Handbook of organization development in schools and colleges. Prospect Heights, IL: Waveland.

Schmuck, R., Bell, S., \& Bell, W. (2012). The handbook of organization development in schools and colleges: Building regenerative capacity (5th ed.). Santa Cruz, CA: Exchange Pointe International.

Senge, P. (1990). The fifth discipline: The art and practice of the learning organization. New York, NY: Doubleday.

Senior, B. (2002). Organisational change (2nd ed.). London, UK: Pearson.

Smith, C. (1995). "The kids: That's what we were about." The social organization of teachers of diverse race and culture in a South African high school: A naturalistic case study (Unpublished doctoral dissertation). University of Oregon, Eugene, OR. 
Smith, C. 2003. Organisation development: What it is and how it works. Grahamstown, RSA: Rhodes University.

Smith, C., \& Mackinnon, M. (2011, March). Organisation development: The argument remains. Paper presented at the Educational Management Association of South Africa Conference, Bellville, RSA.

South African Government. (2013). National Planning Commission. Pretoria, RSA: Author.

Stoll, L. (2003). School culture and improvement. In M. Preedy, R. Glatter, \& C. Wise (Eds.), Strategic leadership and educational improvement (pp. 93-108). London, UK: The Open University.

Van Nistelrooij, A., \& Sminia, H. (2010). Organization development: What's actually happening? Journal of Change Management, 10(4), 409-422. https://doi.org/10.1080/14697017.2010.516487

Weick, K. (2000). Emergent change as a universal in organisations. In M. Beer \& N. Nohria (Eds.), Breaking the code of change (pp. 223-242). Boston, MA. Harvard Business School.

Weisbord, M. (2012). Productive workplaces: Dignity, meaning and community in the 21st century (3rd ed.). San Francisco, CA: Jossey Bass.

Welton, J. (2001). Building capacity to deliver education in South Africa? In Y. Sayed \& J. Jansen (Eds.), Implementing education policies: The South African experience (pp. 174-187). Cape Town, RSA: University of Cape Town.

Wolcott, H. (1990). Writing up qualitative research. Newbury Park, CA: Sage.

Wolcott, H. (1994). Transforming qualitative data: Description, analysis and interpretation. Thousand Oaks, CA: Sage.

Woodman, R. (2014). The science of organizational change and the art of changing organizations. The Journal of Applied Behavioral Science, 50(4), 463-477. https://doi.org/10.1177/0021886314550575

Wooten, K., \& White, L. (1999). Linking OD’s philosophy with justice theory: Postmodern implications. Journal of Organizational Change Management, 12(1), 7-21. https://doi.org/10.1108/09534819910255289

Zayim, M., \& Kondakci, Y. (2015). An exploration of the relationship between readiness for change and organizational trust in Turkish public schools. Educational Management Administration Leadership, 43(4), 610-625. https://doi.org/ $10.1177 / 1741143214523009$ 